\title{
AN ASSAULT ON A PUBLIC OFFICIAL IN THE PENAL CODE OF 1997 AGAINST THE BACKGROUND OF OTHER NORMATIVE CODE SOLUTIONS IN POLAND IN THE 2OTH CENTURY - AN OUTLINE OF THE ISSUES
}

\begin{abstract}
The purpose of this publication is to show different rights protected by law regarding the crime of assault on public officials in various criminal law code solutions in Poland in the 20th century. To achieve the research objectives, we used a comparative-normative method to examine the shape of specific criminal provisions in Poland. The study's results found differences between undemocratic and democratic system, and confirmed that criminal law, in terms of protection of state institutions, is a reflection of the political system of the state. The article presents issues regarding an assault on a public official under the provisions of the legal system in Poland. Different definitions and interpretations of the term 'public official' resulting from the changes in the political system and the law of the country required appropriate legal solutions in the Penal Code. The process of comprehensive systematisation of provisions in the field of substantive criminal law started with the Penal Code of 1932, although it did not include the legal definition of the concept of a public official. The current act of June 6, 1997 and its subsequent amendments introduced a more precise distinction and legal instruments for penalising an assault on a public official.
\end{abstract}

Keywords: public official, assault, law, Criminal Code, political system.

\section{INTRODUCTION}

Polish criminal law, over the 20th century, has evolved and has been transformed, which was undoubtedly dictated by legal and political conditions. In order to present the aforementioned development path, one should focus mainly on three normative acts determining the substantive criminal law system in Poland. The beginning of this process should be seen in the Criminal Code of 1932, the so-called Makarewicz Code, which ordered the applicable provisions previously adapted from the criminal laws of the partitioning powers. In the Penal Code from 1932, the legislator was guided by the principles of subjectivity, individualisation of punishment and humanitarianism, and, above all, introduced in the Polish

1 Julia Kuczur, Student - fourth year of law studies, Adam Mickiewicz University, Poznan, Poland; e-mail: juliak9703@gmail.com. ORCID: 0000-0001-7597-5097.

2 Tomasz Kuczur, DSc PhD, Associate Prof., University Kazimierz Wielki, University in Bydgoszcz, Faculty of Political Sciences and Administration; e-mail: t.kuczur@wp.pl (corresponding author). ORCID: 0000-0002-7010-8207. 
codification of criminal law a division into general and specific. Referring to the research problem outlined in the title, it is worth noting that the penal act of 1932 did not use the concept of a public official. Chapter XLI of the Code concerned crimes strictly official, at the same time in the glossary of statutory expressions, we do not find the specified legal definition of a public official. Designators of this concept are distinguished on the basis of specific duties and rights arising from their functions in relation to the institution of the state. Such a brief explanation of the statutory concept was supplemented by Article $91 \S 5$, in which it was stated that military persons should also be included in the mentioned group. Makarewicz Code was a formal model for subsequent criminal acts arising on the canvas of communist fights for the creation, with the help (or more precisely the supervision of the services of the Soviet Union), of a people's state. Among them, the Penal Code of the Polish Army of September 23, 1944 played a significant role, supplemented successively by relevant decrees and the Act of April 5, 1955 on the transfer to common courts of the existing jurisdiction of military courts in criminal matters of civilians, officers of public security bodies, Civil Militia and Prison Service (Marek, 20007). The evolution of legislation on criminalization and penalization of offenses directed against public (political) authorities and economic interests (which in the post-war period were called counterrevolutionary attacks) led to the formation in the penal code of 1969 of legal norms typical of the assumptions of the so-called real socialism, contained in chapter XIX of the Code (Makowski, 1932; http://ebuw.uw.edu.pl/dlibra/doccontent?id=16090 - as of March 2, 2019). Therefore, the nature and essence of the analysed research problem require defining the notion of a public official during the period of functioning of the undemocratic political system in Poland after 1945, and its modification after 1956, which is enabled by the normative description in the glossary of statutory expressions, in Art. 120 of the Penal Act of 1969. In this case, the legislator indicated that:

"A public official is: a person who is an employee of a state administration, unless he performs only service activities; judge, people's lay judge, prosecutor; a person holding a managerial position or performing functions related to a special responsibility for protecting public order or security, or for protecting social property; a person performing active military service; another person benefiting from a special legal protection provision for public officials" (The Act of 19 April 1969 Penal Code, Art. $120 \S 11$, Journal of Laws 1969 No. 13, item 94).

However, in the current penal code of June 6, 1997, in Article $115 \S 13$, the following issue was casuistically described:

"A public official is: 1) the President of the Republic of Poland; 2) MP, senator, councillor; 2a) member of the European Parliament; 3) a judge, lay judge, prosecutor, officer of the financial preparatory body or the superior body over the financial body of preparatory proceedings, notary public, bailiff, probation officer, trustee, court supervisor and administrator, a person adjudicating in disciplinary bodies operating under the Act; 4) a person who is an employee of a government administration, other state authority or local government, unless they perform only service activities, as well as another person to the extent in which they are entitled to issue administrative decisions; 5) a person who is an employee of a state control body or a local government control body, unless they perform only service activities; 
6) a person holding a managerial position in another state institution; 7) an officer of a body appointed to protect public security or an officer of Prison Service; 8) a person performing active military service, with the exception of territorial military service on disposition; 9) an employee of an international criminal tribunal, unless they perform only service activities" (Act of June 6, 1997 - Penal Code. Art. 115 $\S 13$, Journal of Laws 1997 No. 88, item 553).

The above-mentioned regulations in their original version did not specify the term "person performing a public function" or the term "in connection with performing a public function". This situation initiated a doctrinal dispute regarding the relationship of these concepts to a public official. According to the dominant view, it should be pointed out that these concepts are broader than the circle of designations corresponding to the code definitions. This state of affairs was reflected in the jurisprudence of the Supreme Court (Kardas, 2005). In the judgment of the Supreme Court of November 27, 1999 (file ref. No. WKN 27/00), it was stated that a doctor employed in the public health service can be considered a public official only when his official activities are combined with functions of an administrative nature. At the same time, a person performing active military service (public officer), who is bound by an employment contract and performs it in his private time, conducting the outlined activity, and it will not be related to the status of a soldier, it is not possible to commit a crime, the subject of which may be only the person referred to in Article $115 \S 13$ (Judgment of the Supreme Court of November 27, 2000, file reference number: WKN 27/00).

Along with the amendment to the Penal Code of July 1, 2003, a distinction was made, adding to Article $115 \S 19$ and thus introducing the concept of a person performing a public function, typing that it is

"a public official, a member of a local government, a person employed in an organizational unit with public funds, unless they perform only service activities, as well as another person whose rights and obligations in the field of public activity are specified or recognized by law or an international agreement binding the Republic of Poland" (Penal Code of 1997, art. $115 \S 19$ ).

Consequently, the concept of art. $115 \S 19$ of the Penal Act of 1997, in its collection contains all the addressees to whom the term public official mentioned in Article $115 \S 13$ of the Penal Code of 1997 refers. The cited view is reflected in the thesis of the Supreme Court's decision of 7 May 2012 (file ref. no. V KK 402/11), in which the following statement was used:

"The legislator does not make the status of a person performing a public function conditional on being provided with the competence to issue decisions in the sphere of public activity. There is no such restrictive criterion in the content of art. $115 \S$ 19 of the Criminal Code. As is clear from its wording in fine, a person who in public activities exercises the rights and obligations specified in the Act also performs the public function (...)" (Order of the Supreme Court of 7 May 2012, file reference number: V KK 402/11). 
When analysing the definition of a public official, one should also distinguish "a person performing exclusively service activities" (Dukiet-Nagórska, 2010), who in their action have been deprived of "decision-making slack" and does not perform substantive activities, and thus cannot be qualified to any of the groups covered by art. $115 \S 13$ or 19; from a "person in a managerial position" in accordance with their competence issuing the instructions to the first of the indicated groups (Dukiet-Nagórska, 2010). It is also worth noting that in accordance with the amendment of 22 March 2011, "legal protection provided for public officials during or in connection with the performance of official duties is also used by the public officer if the unlawful attack on his person was undertaken because of his profession or position held" (Penal Code of 1997, art. 231a). In addition, the current Penal Code, together with the amendment of 1 July 2015, also introduced Art. 231b, in which protection was granted to "a person who, in the necessary defence, refutes the attack on any other good protected by law, by protecting security or public order, enjoys legal protection provided for public officials" (Penal Code of 1997, art. 231b) however, it should be excluded from this scope when "the act of the perpetrator of the attack violates only the honour or dignity of that person” (Penal Code of 1997, art. 231b).

\section{ASSAULT ON PUBLIC OFFICIALS IN POLISH CODE SOLUTIONS}

Crimes related to the attack on a public official in the 1997 Criminal Act were collected in Chapter XXIX, however, it should be noted that typifications of this category were also included in Chapter XVII, regarding crimes against the Republic. Among them, in particular, art. 134 of the Criminal Code and 135 of the Criminal Code, and therefore, respectively, the assassination attempt on the life of the President of the Republic of Poland and the assault and insults of the President of the Republic of Poland (Penal Code of 1997, art. 134-135).The criminalization of acts directed against the state is dictated by the legislator's intention that the penal law of 1997 is to safeguard the values presented in the constitution, such as the rule of law, and also aims to protect the constitutional organs of the Republic of Poland. The expression of this concept is the content of art. 128 of the Penal Code, whose subject of protection are the above-mentioned institutions of the Republic of Poland (Penal Code of 1997, see ibid, art. 128). The key element for their separation is the conjunctive fulfilment of two conditions, that is, they must at the same time be constitutional organs, i.e. at least those mentioned in the constitution and the organs of the Republic of Poland (Kardas, 1999). This group can only include entities that carry out standard functions related to the democratic principle of the separation of powers with their activities. The Sejm and Senate are protected by art. 128 of the Penal Code as the legislative core, while the executive should include the President of the Republic of Poland, the President and Vice-President of the Council of Ministers, the Council of Ministers and individual Ministers. The Constitutional Tribunal and State Tribunal, the Supreme Court, as well as the Supreme Administrative Court are protected from among judicial authorities (Regulation of the President of the Republic of July 11, 1932 - Penal Code, art. $94 \S 2$, Journal of Laws 1932 No. 60, item 571).As a conclusion, Chapter XVII is not intended to protect a particular political system, but it is nevertheless intended to protect it against non-constitutional activities aimed at changing it. The presented regulation is a continuation of the Polish criminal law tradition, as it refers to the penal code of J. Makarewicz, who used the terminology of state crimes, which included, inter alia, an attempt on the life and health of the President of the Republic of Poland (Article $94 \S 1$ ) (Regulation of the President of the Republic of July 11, 1932 - 
Penal Code, art. $94 \S 1$ ), an attempt to remove the President from office and seizure of his authority, the use of violence or threats to influence the activities of the President (Article $94 \S 2$ ) (Regulation of the President of the Republic of July 11, 1932 - Penal Code), as well as an attack on the main organs of power (Article 95) (Regulation of the President of the Republic of July 11, 1932 - Penal Code, Art. 95. See on this topic: Marek, 2000). Analysing the issue in question, it is impossible not to notice that the legislature of the Polish People's Republic did not include a legal norm in the penal code of 1969, strictly corresponding to the criminalization of the assault and active attack on the President (the institution of the President did not appear in the Constitution of the PRL), however in art. 126, which criminalized this type of act, the subject matter of the crime was significantly expanded, defined as a public official or a political activist (The Act of 19 April 1969 Penal Code, art. 126). In art. $120 \S 11$ of the Penal Act of 1969, the definition of the concept of a public official is included, which should be understood as designations included in 7 subsets (as already mentioned): as persons who are employees of the state administration, unless they perform exclusively service activities. In addition, a public official within the meaning of art. 120 $\S 11$ is (appropriate direct indication again here):

“judge, people's lay judge and prosecutor; a person holding a managerial position or performing functions related to a special responsibility in another state organizational unit, cooperative organization or other social organization of working people; a person particularly responsible for the protection of public order or security or for the protection of social property; a person performing active military service; another person benefiting from a special provision under legal protection provided for public officials" (The Act of 19 April 1969 Penal Code, art. $120 \S 11$ ).

The seventh subset are also MPs and councillors. On the other hand, a political activist should be understood as a person engaged in political work, but it is not necessarily a permanent function. The essential issue for understanding the principles of the practical application of this provision was to determine the right protected. It is life and health, only of a public official and political activist, which implies the impossibility of cumulative qualification with provisions protecting life and health in general. Freedom may also be the direct object of the assault, but in such a situation a prohibited act may consist only in deprivation of liberty (Andrejew, Świda, Wolter, 1973). In light of this regulation, it can be concluded that all opposition activists associated with movements such as "Solidarity" or "Confederation of Independent Poland" would also be protected, and therefore a series of detentions based on the legal basis of the Decree of 12 December 1981 on martial law should be considered as an offense criminalized in art. 126 of the Criminal Code, which is, in this case, unlawful deprivation of liberty. However, the subject side of the offense is distinguished by its intentionality, and more precisely the direct intention of the attack on a legally protected good, which is, inter alia, the internal security of the State. The constitution of the Polish People's Republic also explicitly indicates other particular values, which include the PRL system, people's power and the fight against capitalism. Legal relativism and the use of criminal law as an element of political struggle is illustrated by the criminal case of Władysław Frasyniuk, who was detained on charges of "organizing and managing strikes in a number of enterprises and institutions in Lower Silesia - inspiring and organizing street protest actions and demonstrations - organizing and managing underground activities of union structures" (File reference number of the IPN: IPN Wr 23/359/9). The degree of 
criminal record of the offense specified in art. $126 \S 1^{3}$ of the Criminal Code of 1969 was emphasized by the legislator by penalizing the preparation for the analysed crime. It is categorized in art. $128 \S 1^{4}$ of this Act, as an offense punishable by imprisonment from one to 10 years. For comparison, the analogous provisions of the currently applicable Penal Code, in principle, do not treat the preparation stage as a form of crime. As an exception, the consumption relationship between art. $128 \S 2$ and art. 134 of the Penal Code from 1997. The provision penalizing the assassination attempt on the life of the President (art. 134), in the current penal code, does not classify this stadial form of origin of the crime as punishable. However, this is supplemented by the provision of art. $128 \S 2$, in which the legislator has penalized preparation for an attack on a constitutional state authority, which of course is also the President of the Republic of Poland (Penal Code of 1997, art. $128 \S 2$ ). It should be noted that for committing a crime of assassination of the President, there is a criminal sanction of not less than 12 years imprisonment. A penalty of 25 years imprisonment or life imprisonment is also possible (Penal Code of 1997, art. 134). It follows that the Polish legislator, classifying this crime as one of the most severe in the Penal Code, assumed that this is, in its very nature, reprehensible and highly socially harmful, regardless of whether the effect of the assassination would be the death of the President or not. The crime is therefore of a formal nature. Such criminalization implies that attempted murder is treated as an accomplished crime. Therefore, the causative action will be any attack that will pose a threat to a good protected by law, which is the life of the President directly, and indirectly the security of the Republic of Poland and the stability of the State. The denomination of a prohibited act thus defined is a reflection of Art. 126 section 2 of the Constitution (Kardas, 1999), in which the legislator made the following statement: "The President of the Republic of Poland watches over the observance of the Constitution, guards the sovereignty and security of the state and the inviolability and integrity of its territory" (The Constitution of the Republic of Poland of April 2, 1997 adopted by the National Assembly on April 2, 1997, adopted by the Nation in a constitutional referendum on May 25, 1997, signed by the President of the Republic of Poland on July 16, 1997, art. 126 section 2, Journal of Laws 1997 No. 78, item 483).Crime under art. 134 may be committed only intentionally. The party can therefore take the form of both direct and resulting intent. In addition, contrary to the Criminal Code of 1969, the current law does not require that the assassination attempt was undertaken for the "enemy of the Polish People's Republic" (Polish Republic), while the previous codification distinguished this directional intention as a sign of an act specified in art. $126 \S 1$ of the Penal Code (from 1969).

At the same time, the described crime does not exhaust the issue related to the broadly understood attack on the President of the Republic of Poland as a public official. An act from art. 135, which is assault and insulting the President, is threatened by much lighter sanctions. This is the equivalent of an active assault on the person of the President of the

\footnotetext{
${ }^{3}$ In accordance with art. $126 \S 1$ "Who, in the hostile purpose of the Polish People's Republic, commits a violent assassination of a public official or a political activist, shall be punishable by imprisonment for not less than 10 years or the death penalty". See: (The Criminal Code of 1969 , art. $126 \S 1)$.

4 The legislator in this provision made the following statement: "§ 1 . Whoever makes preparations for the crime referred to in art. $122,123,124 \S 1$ or 2 , in art. $126 \S 1$ or in art. 127 , is subject to the penalty of deprivation of liberty for a term of between 1 and 10 years". See: (The Criminal Code of 1969, art. $128 \S 1$ ).
} 
Republic of Poland and the offense of insulting the President of the Republic of Poland, which were the first and second paragraphs of art. 125 of the Criminal Code from 1932. At the same time, the criminal law of 1969 did not include a separate legal provision (the lack of the President's institution in the PRL, which was already mentioned), which would strictly reflect the content of the norm from the code of J. Makarewicz. However, criminalizing such behaviour in the Penal Code from 1969 should be seen in art. $126 \S 2$, whose subject matter is based on a violent attack on the health of the officer or political activist or the deprivation of liberty of these persons, as well as in art. 233 and art. 236 regarding an active assault on a public official or a person to help in connection with the performance of official duties and insulting the above-mentioned objects of crime (Kardas, 1999).

For a full understanding of the essence of art. 135 of the current Penal Code, it is necessary to specify the concept of active assault. Interestingly, it had the same connotations under the 1969 Act, the implication of which is that the interpretation developed on the basis of this code is valid in relation to the new CC. The term should be understood as "violent action against the body being attacked, and this action must take the shape of at least an attack on bodily inviolability" (Andrejew et al., 1973). From such a definite feature of the subject side, it follows that the offense is of a formal nature, because there is no need to have any effect of the said action, while the subjective side appears only as a direct intention, as indicated by the hallmarks of causative action. Offense stipulated in art. 135 of the current Code is also a lex specialis in relation to the offenses under Art. 222 and art. 223 and art. 128, relating to the activities of state institutions and local government, as well as the attack on the constitutional body of the Republic of Poland.

\section{INFRINGEMENT OF THE INVIOLABILITY OF A PUBLIC OFFICIAL AND RELATED ACTS CRIME}

The offense of violating the inviolability of an officer, due to a good protected by law related to human dignity, should be considered as a special provision in relation to the offense under Art. 217 of the Penal Code, i.e. violation of inviolability ${ }^{5}$. In turn, the interpretation of this provision is necessarily related to art. 41 of the Polish Constitution ${ }^{6}$, which is a guarantee of inviolability and personal freedom. However, the subject of protection in art.

\footnotetext{
5 The legislator in this provision made the following statement: "§ 1 . Whoever strikes a person or otherwise violates his or her physical integrity, is subject to a fine, the penalty of restriction of liberty or the penalty of deprivation of liberty for up to a year. $\S 2$. If the violation of inviolability was caused by provocative behaviour of the injured person or if the injured person responded by violating inviolability, the court may waive the imposition of a penalty. $\S 3$. The prosecution is based on private prosecution". See: (Penal Code of 1997..., art. 217).

6 The constitution-maker pointed out in this case that: "1. Everyone is guaranteed personal inviolability and personal freedom. Deprivation or restriction of liberty may occur only on the terms and in the manner specified in the Act. 2. Everyone deprived of liberty not on the basis of a court judgment has the right to appeal to a court in order to immediately determine the legality of that deprivation. The imprisonment is immediately notified to the family or person indicated by the deprived of liberty. 3. Everyone detained should be informed immediately and in a manner understandable to him about the reasons for detention. He should be available to the court within 48 hours of his arrest. The detainee should be released if, within 24 hours of being placed at the disposal of the court, he is not served with the court's decision on detention on remand with the charges presented. 4. Everyone deprived of liberty should be treated in a humane manner. 5. Everyone unlawfully deprived of liberty has the right to compensation”. See: (Constitution of 1997..., art. 41).
} 
222 of the current Penal Code (violation of an officer's inviolability) is complex, its important aspect is the proper operation of a state or local government institution that requires attack-free activity that is the subject of a direct action of a public official or a person to help him during or in connection with the performance of official duties (Zoll, 1999). It is worth noting that the complexity of a good protected by law is a phenomenon occurring in crimes in which the causative act clearly harms the life, health or inviolability of man, and thus affects the functioning of broadly understood state organs and the stability of the normative system, as well as the principles of the division of powers. The equivalent of the provision under consideration in the Criminal Act of 1969 is Art. 233, which already in its literal wording indicates differences in the features that determine the causative act, despite the fact that it uses the already described aspects of active assault. The crime features defined in this way have a broader scope than the violation of physical integrity, because they take into account forms constituting an attempt to violate physical integrity, but it should be noted that not all such behaviour can be classified as active assault. According to A. Zoll's view: "It is not an active assault to push an officer away to escape. This behaviour carries the features of physical integrity" (Zoll, 1999). The Penal Code of 1969 also distinguished the qualified type of the above feature, which was specified in art. $234 \S 1$ regarding assault of relatively low social harm. In this case, the set of objects of the crime included both persons such as an officer of the Citizens' Militia (MO) or other body appointed to protect public order and security, as well as an officer of the penitentiary service, the military internal service, the volunteer reserve of MO and the protection of railways. The legislator in $\S 2$ of the said provision, taking into account the serious bodily injury or health disorder of the persons mentioned, provided for a rigorous criminal sanction, namely imprisonment for not less than 3 years. The situation outlined in this way initiated a doctrinal dispute over the subject matter of art. $234 \S 1$ of the Penal Code. The amendment to the penal code of 1995 took into account the postulates presented, however, as a result, all of art. 234 was deleted, although at the same time a more severe penalty was imposed on an act, which resulted in a serious damage to the health of each public official or a helping person. Criminal liability was also tightened on the basis of the Criminal Act of 1997 (Marek, 2000). The legislator in art. $223 \S 2$ stated: "If as a result of an active assault there was an effect in the form of serious damage to the health of a public official or a helping person, the perpetrator shall be subject to the penalty of deprivation of liberty for a term of between 2 and 12 years" ( Penal Code of 1997, art. $223 \S 2$ ).

The act of art. 233 of the Criminal Code from $1969^{7}$ also corresponds to the offence that was criminalized in art. $223 \S 1^{8}$ of the current criminal act. Once again, it should be noted that the jurisprudence line developed on the basis of the no longer binding Penal Code regarding the features of active assault is integral with the understanding of this concept under

${ }^{7}$ In this provision, the legislator made the following statement: "Whoever commits an active assault on a public official or a person to assist in connection with performing official duties shall be subject to the penalty of deprivation of liberty for a term of between 6 months and 5 years".

8 The legislator pointed out in this provision that: "\$ 1 . Who, acting jointly and in agreement with another person or using a firearm, knife or other similarly dangerous object or an incapacitating agent, commits an active assault on a public official or a person to help him during or in connection with the performance of official duties, is subject to the penalty of deprivation of liberty for a term of between 1 and 10 years. § 2 . If as a result of an active assault there was an effect in the form of severe damage to the health of a public official or a person to help him, the perpetrator shall be subject to the penalty of deprivation of liberty for 2 to 12 years. 
current law. However, this does not change the fact that other features determining the causative act of a criminal act under Art. $223 \S 1$ of the Penal Code of 1997 are an interesting research problem. The language interpretation of the provision indicates that active assault must occur in one of two forms that assume "acting jointly and in consultation with another person or using a firearm, knife or other similarly dangerous object or a means of incapacitation" (Penal Code of 1997, art. 233). Thus, it imposes, as a form of committing the crime of complicity, referred to in Article $18 \S 1$ of the Penal Code ${ }^{9}$. According to A. Zoll's view:

"The Act in art. 223 requires qualified complicity in the sense that there must be at least three accomplices. This definition of the method of committing an active assault is justified by the fact that the substance of the offense under Art. 223 is the possibility of a serious threat to the security of a public official or a person taken for his assistance (the crime of abstract exposure to danger)" (Zoll, 1999).

However, M. Bojarski unequivocally stated that "the provision for liability requires that this behaviour be undertaken jointly and in agreement with another person" (Bojarski, 2015). On the other hand, according to A. Zoll, by analogy, in a situation where one or two people are actively assaulted, and they also do not use the hazardous measures referred to in Article 223, such behaviour should be classified as fulfilling the hallmarks of art. 222 . The main determinant for understanding the essence of this legal norm is also the correct interpretation of the other circumstances of the subject party affecting penalisation. First of all, a distinction should be made between the concepts of 'using' and 'utilising'. The first of these terms has a narrower scope, it boils down to using a given object during the implementation of the already mentioned active assault. The second wording, however, whose meaning is best reflected in art. $280 \S 2$ (Zoll, Offenses against state institutions and local government [in:] Penal Code $)^{10}$, according to the opinion of the Supreme Court should be understood as

"(...) manipulation of means, including their presentation. Therefore, any form of demonstrating a firearm, knife or other dangerous object to cause fear and a sense of threat (»intimidation «) will be a form of utilising this object within the meaning of Article $280 \S 2$ of the Criminal Code" (Bojarski, 2015).

The outlined in this way the act of utilising taking place on the side of the subject of the prohibited act in relation to a public official understood as an object may result in the realization of the features of an offense under Art. $224 \S 2$, that is, "forcing a public official or

${ }^{9}$ In accordance with art. $18 \S 1$ of the Penal Code: "Responsible for perpetration not only the person who performs a criminal act alone or jointly and in consultation with another person, but also the one who directs the execution of a criminal act by another person or by using the dependence of another person on himself, recommends that he perform such of deed. Penal Code, art. $18 \S 1$.

${ }^{10}$ In art. 280 the wording was used: " $\$ 1$. Who steals, using violence against a person or threatening to use it immediately or bringing a person to a state of unconsciousness or vulnerability, shall be punishable by imprisonment from 2 to 12 years. $\S 2$. If the perpetrator of robbery uses a firearm, with a knife or other similarly dangerous object or means of incapacitation or acts in a different way directly threatening to life or together with another person who uses such a weapon, object, means or method, shall be punishable by imprisonment for not less than 3 years". See: (Penal Code of $1997 \ldots$, art. 280). 
a person helping him to undertake or abandon legal official activity" (Penal Code of 1997, art. $224 \S 2)$.

\section{INSULTING OF THE PUBLIC OFFICIAL}

An important matter of consideration is also the act under Article $226 \S 1$ of the current Criminal Code, which provides for a fine, restriction of liberty or imprisonment for a year for insulting a public official or a helping person. It is therefore a lex specialis in relation to legi generali that is art. 216 of the Criminal Code ${ }^{11}$, which is insulting a man. Modal circumstances should be indicated as the element differentiating these two provisions, because the first one strictly protects the dignity of a public official or a helping person, while the object of protection of the second one is the implementation of Art. 30 of the Constitution of the Republic of Poland ${ }^{12}$. It should also be noted that the modal features of this crime evolved under the influence of the judgment of the Constitutional Tribunal of October 11, 2006, in which the Constitutional Tribunal decided that art. $226 \S 1$ “( $\ldots)$ to the extent that it penalizes insults on a public official or a helping person made not in public or made publicly, but not while performing official duties, is incompatible with Art. 54 section 1 in connection from art. 31. Section 3 of the Polish Constitution" ${ }^{13}$ After the change in the penal code, two modal circumstances were defined, which must occur conjunctively. The same situation took place under the Criminal Act of 1969.

Following the provision provided for in $\S 3$ art. 216 the court may refrain from imposing a penalty if the features from $\S 1$ and 2 have been fulfilled by the injured party as a result of provocation or retaliation on his side, the legislator also provided for in art. $226 \S 2$ proper application of the provision of art. $222 \S 2^{14}$. This, in turn, indicates that if the act was caused

11 The legislator in the said provision indicated that " $\$ 1$. Whoever insults another person in his presence or even in his absence, but in public or in the intention that insults reach that person, shall be subject to a fine or the penalty of restriction of liberty. $\S 2$. Whoever insults another person by means of mass communication is subject to a fine, the penalty of restriction of liberty or the deprivation of liberty for up to a year. $\S 3$. If the insult was caused by provocative behaviour of the injured party or if the injured party responded by violation of bodily inviolability or mutual insult, the court may waive the imposition of a penalty. $\S 4$. In the event of a conviction for an offense specified in $\S 2$, the court may order an interest for the injured party, the Polish Red Cross or for another social purpose indicated by the injured party. $\S 5$. Prosecution is carried out by private prosecution".

12 The constitution-maker indicates that "Natural and inalienable human dignity is a source of human and citizen freedom and rights. It is inviolable and its respect and protection is the responsibility of the public authorities".

${ }^{13}$ Citation after: Dukiet-Nagórska, 2010. According to art. 54 section 1 "Everyone shall be guaranteed the freedom to express their views and to obtain and disseminate information" 31 section 3 , the constitution-maker indicates that "Restrictions on the use of constitutional freedoms and rights may be established only by law and only when they are necessary in a democratic state for its security or public order, or for the protection of the environment, public health and morality, or freedom and the rights of others. These limitations cannot affect the substance of freedoms and rights.

14 According to the wording of art. 222 of the Penal Code: "§ 1 . Who violates the physical integrity of a public official or a person to help him during or in connection with the performance of official duties, shall be subject to a fine, the penalty of restriction of liberty or the deprivation of liberty for up to 3 years. $\S 2$. If the act specified in $\S 1$ was caused by improper behaviour of an officer or 
by inappropriate behaviour of an officer or person to assist him, the court may apply extraordinary mitigation of punishment, and even renounce its imposition. Whereas in $\S 3$ the qualified type is presented, which consists in insulting or humiliating the constitutional body of the Republic of Poland, i.e. "each body mentioned in the Constitution of the Republic of Poland, i.e. the Sejm, Senate, President of the Republic of Poland, Council of Ministers, Prime Minister, government administration bodies, local government, courts and tribunals, the Supreme Audit Office, the Ombudsman, the National Broadcasting Council." (Cit. after Bojarski [in:] Bojarski, 2015). However, this position is partly in opposition to the opinion of A. Zoll according to which "the President of the Republic of Poland is not directly subject since he is protected against the insults by art. $135 \S 2$ " (Zoll, 1999). The offense under art. $226 \S 3$ will also constitute defamation of the above-mentioned authorities. In this situation, there is a real, but negligible convergence of regulations, by applying the principle of consumption. However, in the remaining scope it is not possible to classify such an act and it should be considered as an offense under Art. $212 \S 1$ or 2 (Zoll, 1999).

\section{SUMMARY}

To sum up, the Makarewicz Code of 1932, in which the legislator initiated the process of comprehensive systematization of provisions in the field of substantive criminal law, did not include the legal definition of the concept of a public official or clerk. However, it distinguished designates of these concepts on the basis of their individualized features, including duties and powers in relations with state institutions, which served as the basis for distinguishing clerical offenses, assembled in chapter XLI of the code. In addition, as mentioned at the beginning, the legislator also included military persons in the analysed group. Whereas art. $120 \S 11$ of the Penal Code of 1969, the legislator clearly defined the designations of the concept of a public official, however, in further provisions, he also uses the concept of a political activist, which in turn does not appear in the glossary of statutory expressions, and at the same time is vague, and thus leaves many possibilities for interpretation. This procedure enabled, in conjunction with the other provisions of the criminal law of 1969, as well as the principles expressed in the Constitution of the Polish People's Republic, instrumental treatment of society, which was deprived of a sense of the guarantee function of the law. At the same time, it should be emphasized that the indicated solution is unacceptable on the basis of generally accepted legislative standards of a democratic state of law. It was only the current criminal act of June 6, 1997, using, among other things, synthetic provisions (Giezek, 2015), that prevented a broad interpretation of the individual, highly rubberized concepts that were applicable under the 1969 Code. Furthermore, the fact that the current Penal Code in comparison with the Constitution of 1997, should be like an emanation of the guarantee function of criminal law, and thus shape the relationship between the individual and the state apparatus in a way that ensures the application of the basic principles of criminal law in line with the constitutional standards of a democratic state of law (Giezek, 2015). In view of the above-proposed statements and referring to specific material rules, it should be recognised that, in the case of law protected rights related to the functioning of institutions belonging to the State, material criminal law is a kind of representation of the political system of the state. If the political system is democratic, then

person to assist him, the court may apply extraordinary mitigation of punishment, and even renounce its imposition". 
criminal law in this area is also democratic; whereas if the political system is undemocratic (totalitarian or authoritarian), then criminal law also (in general) takes that form.

\section{REFERENCES}

Andrejew, I, Świda, W, Wolter, W. (1973). Penal Code with commentary. Warsaw. Bojarski, M. (2015). Offenses against state institutions and local government [in:] Bojarski, M., Giezek, J., Sienkiewicz, Z., ed., Substantive criminal law. General and special part. Warsaw.

Dukiet-Nagórska, T. (2010). Offenses against the activities of state and local government institutions [in:] Dukiet-Nagórska, T., ed., Criminal law, general, specific and military part. Warsaw. Giezek, J. (2015). The concept and functions of criminal law [in:] Bojarski, M., Giezek, J., Sienkiewicz, Z., ed., Substantive criminal law. General and special part. Warsaw.

Kardas, P. (2005). Employment in an organizational unit with public funds as a statutory criterion determining the meaning of the term 'person performing a public function'. Considerations against the background of interpretative models presented in the penal literature and case law of the Supreme Court. "Journal of Criminal Law and Penal Sciences", Vol. 1.

Kardas, P. (1999). Offenses against the Republic of Poland [in:] Bogdan, G., Buchała, K., Ćwiąkalski, Z., Dąbrowska-Kardas, M., Kardas, P., Majewski, J., Rodzynkiewicz, M., Szewczyk, M., Wróbel, W., Zoll, A.,eds., Penal Code. Special part. Commentary on Article 117-277 of the Penal Code. Krakow.

Marek, A. (2000). Penal Law, Warsaw.

Makowski, A. (1932). Penal Code. Commentary, Warsaw.

http://ebuw.uw.edu.pl/dlibra/doccontent?id=16090 - as of March 2, 2019.

\section{LEGAL ACTS}

Regulation of the President of the Republic of July 11, 1932 - Penal Code (Journal of Laws 1932 No. 60, item 571)

The Act of 19 April 1969 Penal Code (Journal of Laws 1969 No. 13, item 94).

The Constitution of the Republic of Poland of April 2, 1997 adopted by the National Assembly on April 2, 1997, adopted by the Nation in a constitutional referendum on May 25, 1997, signed by the President of the Republic of Poland on July 16, 1997 (Journal of Laws 1997 No. 78, item 483).

Act of June 6, 1997 - Penal Code (Journal of Laws 1997 No. 88, item 553).

\section{ORDERS AND JUDGMENTS}

Judgment of the Supreme Court of November 27, 2000, file reference number: WKN 27/00. Order of the Supreme Court of 7 May 2012, file reference number: V KK 402/11.

\section{OTHER SOURCES}

File reference number of the IPN: IPN Wr 23/359/9

DOI: $10.7862 /$ rz.2019.hss.38

The text was submitted to the editorial office: October 2019.

The text was accepted for publication: December 2019. 